\title{
THE SOURCES OF RESILIENCE OF ISLAMIC BANKS TO THE GLOBAL FINANCIAL CRISIS ${ }^{1}$ УЗРОЦИ ОТПОРНОСТИ ИСЛАМСКИХ БАНАКА НА СВЕТСКУ ФИНАНСИЈСКУ КРИЗУ
}

\author{
Ana Maria Cataldi \\ Outsource Insurance Professionals, Beograd \\ Nataša Stanojević ${ }^{2}$ \\ Visoka škola Dositej, Beograd
}

\begin{abstract}
Апстракт: Циљ истраживања је да укаже на далеко већу отпорност исламских банака на негативне ефекте Светске финансијске кризу у односу на конвенционалне банке, као и да открије механизме који спречавају или сманују негативне ефекте кризе. Иран је одабран за студију случаја због највеће распрострањености исламског банкарства у односу на конвенционално. Анализирани су сви узроции финансијске кризе наведени у досадашњим истраживањима истакнутих светских стручњака у овој области: презадуженост, шпекулативне активности, фиктивни новач и камата, финансијска паника. За сваки од извора финансијских криза означене су исламске „, алтернативе“ које су означене као извор отпорности исламских банака. То су: забрана шиекулативних активности И превеликог ризика, забрана камате И неколико исламских модела финансирања.
\end{abstract}

Кључне речи: конвенциионално банкарство, исламско банкарство, финансијска криза, фиктивни новац.

Abstract: The aim of the research is to point to a far greater resilience of Islamic banks to negative effects of the global financial crisis comparing to the conventional banks, as well as to discover the mechanisms that prevent or reduce the negative effects of the crisis. The comparative effects of the global financial crisis on conventional and Islamic banks are given in the first chapter. All causes of financial crisis, listed in the key current research of prominent experts in this field, were analyzed in the second chapter, including indebtedness, speculative activity, interest and fictive money, financial panic. Islamic "alternatives" for each of them were marked as a source of resilience of Islamic banks in the third chapter. These are: prohibition of speculative activities and excessive risks, prohibition of interest and few of Islamic financing models.

Key words: conventional banking, Islamic banking, financial crisis, fictive money.

\section{INTRODUCTION}

This research is based on highlighting differences in the effects of the world financial crisis on two different banking systems - conventional and Islamic banking. A comparative overview of different aspects of the

\footnotetext{
${ }^{1}$ The paper is a part of research on the Ministry of Science project: Enhancing public policies in Serbia as a function of the improvement of social security of citizens and sustainable economic development, III47004.

2 natasa1171@gmail.com
} 
situation and trends in these systems is given in the first part, where the data are presented collectively for conventional and Islamic banks.

The second part analyzes the factors that have been confirmed, in previous research, to be the causes of the financial crisis in general, and especially contemporary world financial crisis that began in 2008. The study does not aim to discover a new cause of the financial crisis, because all potential mechanisms have already been analyzed in the mass of scientific papers over the years. In rough terms, the chain of the main causes of the crisis would look like this: excessive borrowing (indebtedness), which leads to excessive investment based on speculative forecasts, then to excessive capacity, mainly of living space, but sometimes to production capacity; the surplus of capacity leads to a decline in their value, therefore, a decline in the currency value. This is common to all the economies affected by the crisis.

In the third part, the most important principles of Islamic banking are presented, and the mechanisms that strengthen the resilience of these banks in the requested financial crisis or completely prevent the advent that leads to financial crises, are analyzed. These principles are: the prohibition of interest (riba), the prohibition of speculation (maysir) and the excessive uncertainty arising from asymmetric information (gharar), which we consider key to the resilience of banks. Besides these, financial models have an important role, some of which have a direct impact on reducing the sources of the crisis, and some indirect but important role in establishing social stability and preservation of trust in banks.

The aim of the research is to determine which of the causes of the financial crisis are prevented by means of the principles and instruments of Islamic banking system, and which of these factors are regulated in a different way or completely banned in the Islamic banking system. These areas of disagreement, business models or banking practices, for which Islamic banking has different methods, are imposed as a route to establishing more resilient, sustainable operations of conventional banks, possibly as a solution to improve the currently not yet mitigated consequences of the Crises.

\section{THE COMPARATIVE EFFECTS OF THE WORLD FINANCIAL CRISIS ON CONVENTIONAL AND ISLAMIC BANKS}

Banks all over the world have been struggling with the crisis and its consequences since 2008, while the Islamic ones have a completely opposite trend: their assets have been constantly growing. Islamic Banking has been strengthening for the last two to three decades, and its 
recent average rate of about $15 \%$ growth per annum has already made it one of the most popular phenomenon of XXI century.

According to the Islamic Finance and Global Stability study drawn up in 2010 by several eminent financial institutions (Islamic Financial Services Board, Islamic Development Bank and Islamic Research and Training Institute) Islamic banks have shown much higher resilience to the financial crisis. The following data were presented (2010, pp 35-36):

- When it comes to market capitalization, the top ten conventional banks have suffered a decline of $42.8 \%$ compared to $8.5 \%$ decline by Islamic banks in the period between December 2006 and May 2009.

- Total net profit of conventional banks fell dramatically from 116 billion USD in 2006 to 42 billion USD in 2008, or $36.21 \%$. In contrast, Islamic banks net profit grew by $9 \%$ in the same period, from 4.2 billion USD to 4.6 billion USD.

- While 4 out of 10 mentioned conventional banks experienced losses, none of Islamic banks suffered losses in 2008.

- Financial support from the government was received by 5 of the top 10 conventional banks, the aid amounting to 163 billion USD, or $26 \%$ of the total capital of endangered banks. In contrast, only one Islamic financial institution requested assistance from the government, and was turned down by the government. At the end of 2009, none of the Islamic banks needed government assistance.

There is also plenty other evidence of advantage of Islamic over conventional banks:

- Even before the financial crisis, in the period 2006 - 2008, the total assets of conventional banks rose by $36 \%$, ie., to 17.4 trillion USD, while the assets of Islamic banks rose by 55\% and the value of 94 billion USD to 147 billion USD. The growth of total capital during this period was $24 \%$ when it comes to conventional, and $36 \%$ for Islamic banks, so that by 2013 assets of Islamic banks reached 1.800 billion dollars (IMF, 2013).

- On example of Iranian banks, the profitability of banks in 2010-11 compared to $2006-07$ increased to $561 \%$ in a state-owned sector, and $661 \%$ in the private sector. The profitability of these banks on average increased by $358 \%$ in the sector of state ownership and $321 \%$ in the private sector in 2010-11 compared with 2006-07 (Ashraf, Giash, 2011, 40).

- One of conclusion of statistical research of Jordanian banks is that Islamic bank are less risky and more solvent than conventional banks (Milhem, Istaiteyeh, 2015, 37). 
- Ouerghis` $(2014,946)$ statistical research shows that conventional banks are generally more profitable than Islamic banks but, Islamic banks are more profitable in the post crisis period.

- The results of statistical research of Islamic banks in Saudi Arabia also showed that Islamic banks, ,remained unaffected during the global financial crisis“(Tabash, Dhankar, 2014, 386).

\section{THE SOURCES OF SENSITIVITY OF CONVENTIONAL BANKING TO FINANCIAL CRISIS}

The sources of financial crises are relatively simple, fundamentally explained, but that does not reduce the scope of the problem of crisis overcoming. Most analysts agree that these sources are: different levels of speculative activity, excessive indebtedness, financial panic and rarely observed systemic problem of Western economies interest and the creation of banking (fictive) money, which are inextricably linked with excessive credit and speculation. These sources are closely interlinked, interdependent and sometimes their classification is conditional.

\subsection{Over - indebtedness}

In the period of economic growth, the growth of prices, especially in property prices and the growth in deposits, banks and customers become too optimistic, give and take loans too easily, which in turn become larger and larger. Both sides are willing to take greater risks than it is usually the case. Banks do not insist on procedures and prescribed conditions, allow speculative lending, so that loans sometimes become several times greater than the deposit.

Over-indebtedness is a key cause of the crisis according to many economists, starting from Minsky (1992), Kindleberger (2005), to theorists inspired by the crisis of 2008: Alrifat (2015), Keen $(2011,2012)$, Katic (2013) and others.

Minsky considers excessive lending, or borrowing of individuals and companies to be the main cause of the financial crisis. There is the famous Minsky moment that marks the moment in which the indebted clients start to sell assets (mainly real estate) in order to repay debts. Due to urgency of sales, prices drop rapidly, while distrust in banks, the market and the national economy grows progressively. This can lead to financial institutions becoming insolvent, either due to reduced number of clients and the amount of credits, or due to the withdrawal of customers 
because of growing mistrust. Minsky moment is the moment when the level of loans and debt reach an unsustainable level.

Minsky recommends (similar of the regulation of the Islamic banking) a ban on speculative activities and the prevention of the development of the previously described Pontius lending scheme, the requirement that banks have greater liquidity reserves in the form of cash, as well as requiring the banks to contribute to the stabilization funds during the crisis periods and strict regulations concerning mortgage loans.

Kindlberger (2005, pp. 4-5) analyzes over-indebtedness as a cause of the financial crisis in the 1980s in Latin America, particularly in Mexico, Brazil, Argentina. The debt of this group of countries increased from $\$ 125$ billion in 1972 to $\$ 800$ billion in 1982. The direct consequence was a sharp depreciation of the value of local currency, the decline in the value of stocks and the collapse of most banks as a result of huge debt losses.

Besides the excessive spending and borrowing of the public sector, debts of the private sector are more often cited as the causes of the financial crisis (Keen, 2012, Katic, 2013). The private debt is believed to have started the crisis in Iceland, Spain, Portugal, Republic of Korea.

Keen believes that private debt (households and businesses) had a far greater impact on the crisis than external debt. The main cause of the economic and financial crisis that began at the end of 2007 is excessive issuance of credit loans by banks whereby they primarily funded speculations, and not investments.

This caused the unprecedented inflation of private debt, unheard of in human history and the previous century (Keen, 2012, pp. 2).

According to Keen, the recent growth of the national debt is a symptom of the crisis, and not its cause, and the current political obsession to decrease the public debt will only worsen the cause of the problem - the weakening of the private sector. Public debt, as opposed to the private one (households and companies) does not reduce demand. According to Keen (2011, p. 11), the debt increase caused a drop in demand, with $28 \%$ of revenues in 2008 to $20 \%$ in 2010, and he considers this to be the cause of the crisis.

It is obvious that private debt has to be reduced with, at the same time, inflicting the least possible damage to aggregate demand and social equality (Keen, Minsky).

\subsection{Speculative activity in conventional banks}

Commercial banks, which borrow money too easily in order to provide a greater profit, are equally to blame for the excessive lending, as 
well as the individuals and companies that borrow beyond the limits of its capacity. Thus both parties turn out to be prone to risk, that is inclined to risky operations. Banking operations are increasingly exposed to credit risk, which indicates the failure of the banks to settle their claims based on previously approved loans (Dragosavac, 2013, p.41).

Speculative operations range from the border cases, which mean that the expected earnings are sufficient for interests and the repayment of the debt, to the riskiest Pontius (Ponzi) scheme (pyramid scheme), which implies future revenues that are sufficient neither for annuity, nor for interest (Kindlberger, 2005, Juhas, 2011).

The basis of speculation is reselling to create a capital gain. It includes the purchase of goods in order to realize capital gains from the anticipated increase in their prices, rather than their use. In most countries, the financial crisis has started with incredible growth in price of apartments, and therefore extremely active real estate market. This is the least radical form of speculation, but it is not an ordinary resale, at which the value obtained by reselling is different from purchasing only by maximizing the reseller's service. Considering the fact that capital gains are acquired, this is far from trade and rational behavior. It is rather described as a "mania" or "bubble".

The most extreme form of speculation is the Ponzi's or the pyramid scheme, which typically includes a promise of interest rates of 30 to 40 , or even 50 percent per month. These banks, usually new on the market, repay the promised interest rates in the first few months with the money received from new customers, which are attracted by the promised interest in increasing numbers (Kindleberger, 2015, p. 13), and the proof that it has already been repaid to someone. It is usually after 4 to 5 months that the funds received from new customers become smaller than the promised interest, not because there are no new depositors, but because interest rates are extremely unrealistic. The owners of these banks usually emigrate from the country in less than a year since their foundation.

This phenomenon is related to the so-called "moral hazard" (Krugman, 2009). Moral hazard occurs when companies or banks behave carelessly because they know they would be saved if things should develop in an unwanted direction.

Alrifai (2014, p. 89) also mentions the moral hazard of conventional banks, especially the largest ones, because they have the protection of their governments, which save them when they get to the verge of bankruptcy by excessive risk-taking. Governments themselves lead to the spread of risky operations of these banks, calling them "too big to fail", which encourages their increasingly reckless, even criminal business operations (with terrorist organizations, the mafia, etc.). 
Prices keep growing, which encourages the expectations that this trend will continue, so that a growing number of entrepreneurs and citizens engage in speculative activities, expecting further price hikes. At some point, a saturation of the market (mainly real estate) occurs, sales fall sharply, the prices too, and the expectations of speculators fail along with the fall in the value into which they have invested. In the US, at a certain point, the value of mortgages reached such a level, due to the constant growth of interest rates, that users were no longer able to repay them. What happens then is the so-called "bubble burst", leading to losses not only for those who have taken loans, but also the banks that can no longer collect their funds.

\subsection{The interest, fictive money and financial crisis}

By providing loans banks create (without issuing it) the so-called gyro, book or bank money.

Banks grant loans via cashless money transfer. Transferred money is created by the banks themselves, it does not exist. By giving loans, in fact, new money is created, which has never been printed. However, there is an equal demand for it and its value is as great as the value of printed money or coins. Banks create money by means of the "monetization of assets" mechanism. Banks' lending activity enables a bank to create money by monetizing their assets. The most common and the most typical case of the creation of money is when the bank approves a loan to one of its clients. Banking assets do not refer only to property, but also the debt. When a customer signs a loan agreement with a bank to borrow 100000 euros, for example, with the participation of 20000 euros, the bank's assets do not include only the 20000 given, but all 100 000, the amount which does not exist except in the announcement. Furthermore, the bank has free disposal of that amount as of its own property. Therefore, the mere signature of the customer on the loan contract has 'made' money to the bank (Maravić, Milenkovic, pp. 297).

However, the "created" money itself does not make the bank's profit, because they do not take it and spend it, and when the borrower repays the debt, it disappears. In today's conventional electronic commerce, particularly on the interbank market, the non-existent money can circulate very long before someone takes it in its material form. However, (there is a fundamental difference here between Islamic and Western banks) for the period until debt payment, or until someone collects this money in cash, the bank charges interest on this nonexistent money. Gyro money, together with interest, far exceeds the scope of monetary mass produced and put into circulation by the state. 
Another mechanism of money creation by the banks is "deposit multiplication". It is similar to the "monetization of assets," except that fictive money is not instantly created, but first, the real money that customer has paid in cash to his account, is converted into fictive, and then used further. Again charging the interest, of course.

What is the relationship between the fictive money and the financial crisis? Perhaps it is the crucial thing, because it lies at the root of other listed, described, documented and widely recognized causes of the crisis: the speculative activities based on the investment in the projected price growth, for which funds are procured by taking loans which banks grant too easily and excessively, and which, as already described, lead to indebtedness of economy and citizens. The point is that the whole chain of the crisis would not exist if banks gave loans in cash which they really have, only in accordance only with their own interests of having these funds returned to them. However, the fictive money allows the banks, and even encourages them to easy and excessive lending, in order to make as much profit from the interest as possible until the moment the fictitious assets have to be paid out in the physical form. Huge financial assets, nonexistent, but available for further placement, are important as long as they bring interest. Only then it becomes the profit of the bank.

\subsection{Financial panic}

The financial panic may be the cause of the crisis, or at least the cause of the crisis expansion in the event of weak, small economies or in the more indebted countries. However, sometimes this phenomenon also emerges in large, prosperous economies with rapid growth, whose success is still not yet considered to be stable, because of the development, which is a new phenomenon. In economies that do not have the confidence of foreign creditors and investors, all funds are withdrawn and new loans suspended at the first sign of weakness of these economies. At this point there is an inevitable outbreak of the financial crisis.

The financial panic brought about the collapse of the banking system during the Great Depression of 1929-1933 (Alrifai, 2015, pp. 27).

Financial panic was a key factor in the collapse of the economies of Southeast Asia during the Asian financial crisis in 1997. This is not an ordinary panic of the uninformed shareholders or investors. That was the kind of panic in the economy, which, regardless of what it was caused by, "justifies itself - the very panic causes the consequences which support it" (Krugman, 2009, p. 93). This effect is known as the "self-fulfilling prophecy". For example, when all depositors of a bank withdraw money because they had heard that the bank would go bankrupt, and it really 
goes bankrupt, because it is forced to sell its assets below the price in order to repay the creditors. This happens regardless of whether the bank really had problems or not.

According to Krugman, the fact that investors pull money out of a country is enough to reduce the value of the domestic currency. But that is not the end, a drop in the value of the currency, related to the growth in interest rates, leads to financial problems of companies and banks, which further lead to the decline in confidence, creating thus a vicious circle, which, in the case of Asian economies, culminated with the complete collapse of the economy.

\section{THE MECHANISMS OF PREVENTION OF FINANCIAL CRISIS IN ISLAMIC BANKING}

Islamic banking system in many ways prevents the occurrence of a financial crisis. First, speculations are directly prohibited while excessive borrowing of individuals and companies is prevented in several ways. One is the prohibition of interest, which is the most common reason for careless lending by banks and the impossibility for the loans to be returned. The second involves a whole range of models of financing by Islamic banks that are based on the split of profits between banks and borrowers.

\subsection{Prohibition of speculation and excessive uncertainty}

The risk factor is the central argument in Islamic finance. Prohibition of speculation (maysir), as well as the prohibition of excessive uncertainty (gharar) arising from asymmetric information implies a ban on increasing property by means of speculation, and income based on lottery instead of hard work and production efforts. In practice, the difference between speculation and productive effort is pretty blurred.

The concept of prohibition of a gharar contract refers to uncertain or disputed contracts, such as undertaking business ventures without sufficient information or taking excessive risks. It is compared with asymmetric information. The aim is to reduce the possibility of misunderstanding and conflicts between the contracting parties. It is important that the elements of the contract should be clearly defined. As an example of gharar we can take the selling of: fish in the water, cattle which is not born, butter not yet extracted from milk, fruit that is not ripe yet; selling of goods with the buyer not having the possibility to see it, inspect it or get to know it better; selling of products which will be 
shipped in a few years; selling of goods before we have become its owners, the non-existent goods, etc. (Hadžić, 2005, pp. 236).

Conventional banks also have strict procedures and strictly prescribed criteria, but facing the challenges of small profit, all financial institutions succumb to temptation. If the bank, before the peak of the crisis, timely stops further investment, it will make a huge profit, and if this is not done at the right time, it will go bankrupt. In the latter case, no one bears individual blame for its failure. On the contrary, the principle of the prohibition of speculation in Islamic banks, as well as other principles, is above profit, and the consequences of their violation are subject to investigation by special committees which determine the individual guilt, whether the bank has profited or lost its assets.

\subsection{Prohibition of interest}

A key principle of Islamic business and the main difference between Islamic and conventional banking is the prohibition of interest. In the Arabic language interest is known as Riba, and its etymological meaning is to increase, to rise, to extend. Shortly, the Riba indicates the excess (compared to the nominal value of the debt), which the borrower pays to the lender on the borrowed amount. Over time a comprehensive and clearer definition of Riba was conceived, which reads: "Technically, riba refers to the 'premium' that the debtor must pay to the borrower together with the principal amount as a condition for a loan or the extension of the loan. At least four characteristics define a prohibited interest rate: 1) it is positive and fixed ex ante, 2) it is related to the time period and the amount of the loan, 3) its payment is guaranteed regardless of the outcome of the business activity or the purpose to which the principal is borrowed and 4) state authorities approve and (if necessary) conduct its collection". The given riba qualities clearly show that the terms riba and interest, which is applied in conventional finance, are identical.

The prohibition of interest has disabled the use of conventional forms of financing and encouraged the Sharia and financial experts to develop an alternative way of financial operations. The main objective was to conceptualize correct financing arrangements according to Sharia law, which should yield income to funders on non-interest basis.

Islamic banks also "make money", but by returning the debt, money supply returns to normal, while in liberal economies it is constantly increased with new interest. 


\subsection{Islamic alternative funding models}

Apart from direct prohibition of speculation, uncertainty and interest, the Islamic banking has developed alternative funding models based on risk sharing between the Bank and the users of capital. This principle has led to the numerous inventions of Islamic banks in terms of creative financing solutions such as: mudareb, musharek, murabah, ijarah, istisna, mukared and kard hasen. Banks rely on some (or all) of the given forms of financial instruments, whereby some of them are considered a key factor of resilience of Islamic banks to financial crises.

The essence of these agreements is that the financier does not have the role of creditor, like in the conventional financial system, but the role of an investor or a partner, depending on the type of contract. By investing money, financiers acquire ownership shares in a funded project and take over the risk of business failure. Income, which financiers in these financial arrangements can expect, is not guaranteed, fixed and predetermined (in terms of nominal value, fixed or variable rate of return on investment), but depends on the amount of profit from the funded business.

In Islamic legislation, Mudareba is defined as a form of partnership whereby one partner provides the necessary capital (the bank), and the other invests their time, skills, and work in order to make a profit from a partnership transaction together. The particularity of a mudareba contract lies in the fact that the investor plays the role of a passive partner whose management rights are very limited. The investor has a high level of control only in approving requests, i.e. projects in which they will invest.

The freedom of client's functioning is not the same in all forms of mudareba. If the client has acted contrary to the provisions of the contract, the mudareba can be broken. In that case the client has the obligation to return the investor's stake, and in some cases to pay certain penalties. The investor cannot hold the amount charged on the basis of the penalty, because in that case the penalties would acquire the form of penalty interest, which is forbidden in the Islamic business. It is recommended that such amount be paid to charity.

The Islamic financial system implies that capital must be in liquid form, i.e. mortgages are not acceptable. The division of profit can be made only after the business is completed, after which the calculations are made and the obtained results calculated. If the profit made is higher than the deposited amount, the implemented project is profitable.

Risk-taking leads to another characteristic of this type of financing, crucial for the resilience to the financial crises, and that is the 
division of loss. According to the principles of Islamic business, loss can be borne only by a partner who has invested capital in the business. In other words, a complete burden of the loss is borne by the bank, while the client bears the burden of wasted time and effort, which did not result in the desired income. The loss borne by investors is not uncertain either: since there is no interest, the loss is limited by the height of their stake role. The customer bears the burden of loss if the loss is made due to his negligence, fraud or irresponsible behavior. Then he is obliged to cover the loss, return the full amount of the investment to the investor, and in some cases pay some penalties, which the investor deals with as described above.

Sharia principles make it possible to define the terms in the agreement under which a partner can get out of mudareba business before its completion. This can be of great importance since it provides stability, continuity and the increasing attractiveness on the market.

Mushareka is a classic partnership agreement between the two sides, in which one of the key principles of Islamic banking is represented in the clearest way, the principle of division of profit and loss. Mushareka is not solely a banking operation, but can be very useful for successful and efficient operations of the bank. According to this contract, all contracting parties invest a certain amount of money in the business and have the right to manage the project.

A mandatory element of the contract is the agreement on participation in the profit of business partners. Determining the income from the mushareka business is completely different from the approach that exists when determining the interest and its payment. In mushareka contracts the amount of the partners' share in the profit cannot be defined as a predetermined fixed amount or the percentage of the stake, but only as a percentage of the generated profit. In this way, all partners take the risk of failure of initiated project, ie their earnings are entirely related to the profit of the project.

Today, murabaha is the most important and most widely used instrument of Islamic banking. This is a contract of sale or resale of goods per procurement price plus a certain profit. The bank buys equipment, commodities, and materials that are needed for its client, because he has no assets. The client previously gives the exact specification of what he needs and is bound by the contract to take over goods from the bank, since it provides the goods under most favourable conditions.

In this way, the client can obtain what he needs right now, and repay later or through installments. The Bank shall sell the subject of contract to a client at a higher price than the procurement one since it 
must charge the commission too. The fee or profit of the bank from this business transaction is known in advance, and agreed by both parties.

In relation to mudareba and mushareka, this is less risky instrument, and has consequently been spreading in recent years throughout the Islamic world.

Ijarah - like in the case of murabaha, the bank buys what is necessary to its client, but rather rents that instead of selling it to the client. This is not a commercial transaction, but a form of "leasing", even though, as a rule, the client agrees, upon the expiry of the time in which they leased certain equipment, goods or other similar assets, to buy out the given assets (paying value of not depreciated labor).

This is applicable in situations where the lease term (determined by the agreement) is shorter than the economic lifetime of the object of the contract, starting from the realistic assumption that the client will then be in a financial position to do so, and the fact that the bank does not need such equipment that it rented to his client. After the expiry of the contract, the customer has the possibility to return the leased assets to the lessor and replace the existing equipment with new, modern one.

Salam means that the customer pays in advance for a certain quantity and quality of the product that will be delivered to a specified date, at an agreed price. This financial technique, similar to the contract of purchasing in advance, is used in cases where the seller needs capital before they are able to deliver the goods (Hadzic, 2005, p. 32).

Istisna is a contract in which the user starts production of a specific product that can be made only with the approval, monitoring and financial support from banks, and with a secure agreement concerning details, with a certain price and a fixed delivery date (Bakšić, 2012). A customer orders from the manufacturer to produce a certain good for him. Thereby, it is not necessary that the price should be fully pre-paid, which is the case with salam. This undertaking of production includes the process of developing, constructing, assembling or packaging. The difference from murabeha, as a financing instrument, is that in the first case, the sale may refer to something that did not exist at the time of conclusion of the contract, while with murabaha, the subject of purchase can only refer to the goods that exist and can be found on the market. When producers start the works, a contract cannot be unilaterally terminated.

These models have numerous advantages compared to conventional bank loans: they reduce risk and speculation, the absence of interest prevents the creation of fictive money, increases social security and trust in the banks and thereby reduces the likelihood of financial panic, at least of that intensity which could jeopardize the whole financial 
system of country. They have positive impact on the system by disabling the last cause of the crisis - excessive borrowing. Excessive borrowing in Islamic banks, if they comply with Islamic principles, is practically impossible. The Islamic financial system rejects the concept according to which the borrower is obliged to repay the debt, or debt capital, regardless of the execution of work. Instead of that, the lender takes upon himself the risk of the borrower and participates in the profits and losses of the job (Maravić, Milenkovic, 2012).

Kard Hasan is a model of financing that does not directly affect the resilience to the financial crisis, but by strengthening confidence in the banks, it indirectly makes the whole banking system more resilient to external shocks. Kard hasan is a form of interest-free loan. The bank borrows to the client a certain amount, and he is obliged to repay only the principal after the expiry of the deadline. These loans are given without any conditions attached. The bank usually approves this type of loan to those customers with whom it has established regular business cooperation on mudareba or murabaha principles, or with those to whom it knowingly wants to help in the implementation of the job, or a specific project. Kard Hasen is aimed at students, economically weaker clients, the clients with whom the bank already has a relationship based on mudareba or mushareka, and who have faced problems in the implementation of some of the projects.

\section{CONCLUSION}

The global financial crisis has severely shaken global financial system by creating a number of uncertainties on the market, while many of the largest and strongest economies in the world have recorded negative growth rates. The conventional banking system is going through its worst crisis in history and manages to survive only owing to direct government intervention (political measures).

During this period (2008-2016), in contrast to the conventional ones, Islamic banks have not shown any signs of weakening. On the contrary, they are experiencing a real expansion, not only in Islamic countries, but in the UK, France, Germany, Luxembourg and many other non-Islamic areas as well.

Islamic, like conventional banking, is commercially and generates large revenues, and Islamic banks are far from charitable organizations. However, the difference between conventional and Islamic banks is in the approach to the basically same objective, profit.

The primary focus of conventional banks is on bigger and quicker profits, without an insight into the wider context of the condition of the 
economy and society, on which, after all, the bank itself depends. Another factor is the absence of long-term strategy, i.e. the lack of interest for the future, which is why the growth in profits at the expense of clients has returned to banks like a boomerang. After they have strongly contributed to the impoverishment of the economy, they have impoverished the basis of their earnings as well.

Islamic economics as a whole focuses on the sustainability of the whole society, thus compelling banks to base their own success on the success of their clients, not on their impoverishment. Islamic banks do not support the success of their clients at their own expense. However, the fact is that their profit is proportional to the profits of their customers. This is provided by models of financing which are based on shared risk and profits.

Islamic financial instruments have evolved and reached a remarkable level only in the last twenty years. They proved to have an outstanding combination of strength and flexibility during the World Financial Crisis. Islamic financial instruments offer to depositors and investors an alternative to classical instruments. The leading world economists believe that Islamic banking and its instruments have great potential and advantages in the domain of share capital and share risks, unlike conventional ones, which are based on interest and debt instruments.

Even the renowned financial crises economists, who have never borne in mind, or at least never mentioned Islamic banking in their works, recommend measures that are already included in the concept of Islamic economics and banking for the suppression of the financial crisis. An effective example can be found in one of the most acknowledged theorists of a Financial Crisis, Minsky. Most of his recommendations, with the exception of those involving the regulation of interest rates, are very reminiscent of the regulation of the Islamic banking.

Let us summarize the research results of the effects of Islamic banking principles which make these banks much more resilient to the financial crises than conventional. and excessive risks:

The positive effects of the prohibition of speculative activities

- Prevention of irrational and excessive lending by the banks, or the prevention of excessive lending and borrowing as a key cause of financial crises.

- Saving the banking system from the risk of bankruptcy by the introduction of personal responsibility for violating procedures on the Prohibition of risks.

The positive effects of the prohibition of interest: 
- Direct effects of preventing enlargement of fictive (banking) money, as one of the key sources of the excessive lending, speculative activity, the excessive investment and borrowing.

- Direct positive effects concerning financial certainty of enterprises and citizens, which prevent the spread of panic in crisis situations, and the withdrawal of money and banks.

- The indirect positive effects on the financial stability of companies and the population.

The positive effects of Islamic financing models:

- Clients are not exposed to risk of debts that they cannot repay because it is not in the baking commissions' interest to approve a loan to a customer who does not have a strong basis to return it.

- Banks provide significant sources of income that do not involve interest. Without interest, the possibility for the success of the client increases additionally, and of the bank as well.

- They support the launch of new business activities in stable periods, ie. maintaining the level of operations in the conditions of financial crisis in the region.

- Although they do not have a direct impact on the major causes of the financial crises, kard hasan as a duty of the banks and zekat as an obligation of all companies contribute significantly to the preservation of trust in the state, the government, the local economy and the banking system, thereby indirectly preventing the occurrence of panic, which has led to the collapse of a large number of perhaps stable banks in market economies.

\section{REFERENCES}

1. Alrifai, T. (2015). Islamic Finance and the New Financial System. John Wiley \& Sons Singapore.

2. Ashraf, H.\& Giashi, A. (2011). Islamic Banking in Iran - Progress and challenges. Kuwait Chapter of Arabian Journal of Business and Management Review Vol. 1, No. 2. Available at www.omicsonline.com/open-access/islamic-banking-in-iranprogress-and-challenges-2224-8358-1-116.pdf.

Assessed 19.02.2017.

3. Bakšic, E. (2012). Islamsko bankarstvo. Available at http://www.zeriislam.com/artikulli.php?id=2452,Assessed 19.02.2017.

4. Dragosavac, M. (2013). Credit Risk Management System in Commercial Banking, Ekonomski pogledi, 15(4), 41-58. 
5. Hadžić, F. (2005). Islamsko bankarstvo i ekonomski razvoj. Sarajevo: Ekonomski fakultet.

6. International Monetary Fund (2013) The IMF and Islamic Finance, Available at: http://www.imf.org/external/themes/islamicfinance/

7. Islamic Financial Services Board, Islamic Development Bank, Islamic Research and Training Institute (2010). Islamic Finance and Global Stability, Available at http://www.ifsb.org/docs/IFSBIRTI-IDB2010.pdf, Assessed 06.09.2016.

8. Juhas, G. (2011). Sekjuritizacija kredita i uzroci, Ekonomski pogledi, 13(1), 101-125.

9. Katic, N. (2013). Svetska ekonomska kriza - stvarnost, mitovi $i$ poruke. Available at https://nkatic.files.wordpress.com/2013/03/ svetska_ekonomska_kriza_katic.pdf, Assessed 06.09.2016.

10. Keen, S. (2011). Debunking Economics: the naked emperor dethroned? London: Zed Books.

11. Keen, S. (2012). The Debtwatch Manifesto. Available at www.debtdeflation.com/blogs/manifesto, Assessed 06.12.2016.

12. Kindleberger Ch., Aliber R. (2005). Manias, Panics, and Crashes - A History of Financial Crises. Wiley.

13. Krugman, P. (2009). The Return of Depression Economics and the Crisis of 2008. W. W. Norton \& Company.

14. Maravić, D., Milenković N., (2012). Interest-free banking and Economic Development. Megatrend review, 9(1), 285-300.

15. Milhem, M. M., Istaiteyeh, R.M.S. (2015). Financial Performance of Islamic and Conventional Banks: Evidence from Jordan, Global Journal of Business Research, 9(3), 27-41.

16. Minsky, P.H. (1992). The Financial Instability Hypothesis. Working Paper No. 74. The Jerome Levy Economics Institute of Bard College.

17. Ouerghi, F. (2014). Are Islamic Banks More Resilient to Global Financial Crisis than Conventional Banks? Asian Economic and Financial Review, 4(7), 941-955.

18. Tabash, M.I, Dhankar R.S (2014). The Impact of Global Financial Crisis on the Stability of Islamic Banks: An Empirical Evidence, Journal of Islamic Banking and Finance, 2(1), 367-388. 